\title{
Analisis Perbandingan Tingkat Pengembalian dan Risiko antara Indeks Saham Syariah dan Indeks Saham Konvensional di Bursa Efek Indonesia
}

\author{
Dian Rukmini ${ }^{1 *}$, Mochammad Nugraha Reza Pradana ${ }^{2)}$ \\ ${ }^{1 * 2)}$ Fakultas Bisnis, Universitas Universal \\ e-mail: cmeifang20@yahoo.com ${ }^{1 *}$
}

\begin{abstract}
Penelitian ini bertujuan untuk mengetahui apakah terdapat perbedaan tingkat pengembalian dan risiko antara indeks saham syariah dan konvensional. Penelitian ini menggunakan indeks saham JII dan LQ45 pada periode penelitian 2014 sampai dengan 2018. Data yang digunakan dalam penelitian ini merupakan data sekunder yang bersumber dari harga penutupan saham pada Bursa Efek Indonesia. Metode statisika yang digunakan untuk pengujian hipotesis adalah uji mann whitney.Hasil dari penelitian ini menunjukkan bahwa tidak terdapat perbedaan antara tingkat pengembalian dan risiko antara indeks saham JII dan LQ45. Hal ini menunjukkan bahwa kriteria penyaringan yang diterapkan untuk saham syariah tidak mempengaruhi kinerja saham dibandingkan dengan saham konvensional. Sebagian besar saham yang termasuk dalam indeks saham JII juga termasuk dalam indeks LQ45 yang berarti sebagian besar indeks saham syariah merupakan kapitalisasi pasar besar dan likuiditas tinggi.
\end{abstract}

Kata Kunci: Tingkat Pengembalian, Risiko, Indeks Saham

\begin{abstract}
This study aims to determine whether there are differences in rates of return and risk between shariah and conventional stock indices. This study uses stock indexes JII and LQ45 in the 2014 research period up to 2018. The data used in this study is secondary data sourced from the closing price of shares on the Indonesia Stock Exchange. The static method used for hypothesis testing is Mann Whitney's test. The result of this study indicates that there is no difference between the rate of return and risk between the JII and LQ45 stock indexes. This shows that the screening criteria applied to Islamic stocks does not affect stock performance compared to conventional shares. Most of the shares included in the JII stock index are also included in the LQ45 index which means that the majority of Islamic stock indexes are large market capitalization and high liquidity.
\end{abstract}

Keywords: Return, Risk, Stock Index

\section{PENDAHULUAN}

Pasar modal adalah suatu instrumen penting dalam sistem perekonomian sebagai lembaga investasi dan penghimpun dana untuk suatu perusahaan. Pasar modal sebagai lembaga investasi memiliki kaitan yang erat dengan investor selaku pihak yang melakukan investasi. Investasi merupakan komitmen atas sejumlah dana yang dilakukan saat ini dengan tujuan memperoleh keuntungan di masa yang akan datang. 
Saham (stock) merupakan salah satu instrumen pasar keuangan yang paling popular. Menerbitkan saham merupakan salah satu pilihan perusahaan ketika memutuskan untuk pendanaan perusahaan. Pada sisi yang lain, saham merupakan instrumen investasi yang banyak dipilih para investor karena saham mampu memberikan tingkat keuntungan yang menarik (PT Bursa Efek Indonesia, 2018).

Investasi dapat diartikan sebagai komitmen atas sejumlah dana atau sumberdaya lainnya yang dilakukan pada saat ini, dengan tujuan memperoleh sejumlah keuntungan di masa mendatang (Tandelilin, 2010). Indonesia memiliki minat investasi saham yang rendah. Berdasarkan Survei Nasional Literasi dan Inklusi Keuangan (SNLIK) kedua yang dilakukan Otoritas Jasa Keuangan (OJK) pada tahun 2016 menunjukkan indeks literasi pasar modal sebesar 4,40\% dan indeks inklusi pasar modal sebesar 1,25\%. Angka tersebut meningkat dibanding hasil SNLIK pada tahun 2013, yaitu indeks literasi pasar modal sebesar 3,79\% dan indeks inklusi pasar modal sebesar 0,11\% (Otoritas Jasa Keuangan, 2016).

Pada institusi pasar modal, Bursa Efek Indonesia mencatat jumlah investor syariah per kuartal I - 2019 mencapai 50.048 investor. Rasio jumlah investor syariah tersebut setara dengan 5,6\% dari jumlah investor pasar modal . Data tersebut menggambarkan masih minimnya peran investor syariah pada negara Indonesia yang penduduknya mayoritas muslim. Hal tersebut juga diperkuat dari data jumlah investor syariah yang aktif (bertransaksi minimal satu bulan sekali) yaitu hanya berkisar 19\% (Qalbi, 2019).

Penilaian investor terhadap suatu saham perusahaan diantaranya adalah dengan memperhatikan kinerja perusahaan yang menerbitkan saham, selain melihat kinerja sebaiknya investor mengikutsertakan faktor risiko dibalik tingkat pengembalian yang diperoleh. Investor dalam mengukur kinerja kumpulan saham (portofolio) dapat menggunakan tingkat pengembalian dan risiko.

Indeks secara umum dapat didefiniskan sebagai kumpulan saham yang memiliki kriteria tertentu. Secara umum dapat dibedakan dalam dua jenis, yaitu indeks syariah dan indeks konvensional. Secara umum kegiatan pasar modal syariah tidak memiliki perbedaan dengan pasar modal konvensional, namun terdapat beberapa karakteristik khusus pasar modal syariah yaitu bahwa produk dan mekanisme transaksi tidak bertentangan dengan prinsip-prinsip syariah.Walkshäusl \& Lobe (2012) investasi dalam instrumen keuangan seperti saham preferen dan obligasi tidak dapat diterima dalam hukum islam karena menjanjikan tingkat pengembalian tetap dan tidak memberikan hak memilih. Hussein \& Omran (2005) berpendapat bahwa ketika tingkat utang di perusahaan lebih dari sepertiga kapitalisasi pasar, perusahaan tersebut tidak termasuk dalam kriteria Syariah.

Saham yang masuk dalam indeks syariah adalah emiten yang kegiatan usahanya tidak bertentangan dengan syariah seperti (1) usaha perjudian dan permainan yang tergolong judi atau perdagangan yang dilarang dan asuransi konvesional, (2) Usaha lembaga keuangan konvesional, (3) Usaha yang memproduksi, mendistribusi dan /atau menyediakan barang-barang dan /atau jasayang 
merusak moral dan bersifat mudharat (Sinarti, 2010). Sedangkan saham yang tidak tercatat dalam index syariah disebut juga saham biasa.

Di Indonesia indeks syariah terdiri dari beberapa indeks, salah satunya adalah Jakarta Islamic Index (JII), sedangkan indeks konvensional salah satunya adalah indeks LQ45 (Hartono, 2016). JII menggunakan 30 emiten yang masuk dalam kriteria syariah (Daftar Efek Syariah yang diterbikan oleh Bapepam-LK) dan termasuk saham yang memiliki kapitalisasi besar dan likuiditas tinggi. Indeks LQ45 menggunakan 45 emiten yang dipilih berdasarkan pertimbangan likuiditas dan kapitalisasi pasar, dengan kriteria-kriteria yang telah ditentukan.

Penelitian mengenai kinerja saham syariah di Indonesia dan perbandingannya dengan kinerja saham konvesional serta penelitian mengenai faktor-faktor yang memengaruhi kinerja keuangan, dalam hal ini tingkat pengembalian dan saham sangat penting untuk dilakukan mengingat potensi yang dimiliki oleh investasi dalam efek syariah. Penelitian mengenai kinerja saham syariah akan sangat baik apabila dilakukan pada Bursa Efek yang memiliki investor muslim dan penduduk muslim mayoritas seperti di Indonesia, dengan jumlah penduduk muslim mencapai 87,18 persen dari total 237.641 .326 jumlah penduduknya (BPS, 2010).

Beberapa peneliti berbeda pendapat mengenai kinerja saham syariah dan konvensional mengenai pertanyaan apakah kinerja saham syariah lebih baik dibandingkan dengan saham konvensional, begitu pula sebaliknya. Salah satu pihak mengatakan bahwa seharusnya perbedaan antara kinerja saham syariah dan saham konvensioanal sangat kecil (Abbes, 2012). Pihak lain berpendapat bahwa saham konvensional seharusnya memiliki kinerja lebih baik dibandingkan dengan saham syariah (McGowan, Jr. \& Muhammad, 2016). Pandangan ini didasarkan pada fakta bahwa saham atau perusahaan yang mematuhi Syariah mengalami aktivitas ekonomi terbatas karena dua alasan. Pertama, pembatasan Syariah membatasi kemampuan perusahaan untuk menggunakan sumber pendanaan eksternal dan batasan ini mengurangi pertumbuhan berkelanjutan perusahaan. Kedua, pembatasan Syariah membatasi peluang investasi sehingga potensi pendapatan perusahaan berpotensi berkurang. Berdasarkan uraian tersebut, maka peneliti tertarik untuk melakukan penelitian dengan judul Perbandingan Tingkat Pengembalian dan Risiko antara Indeks Saham Syariah dan Indeks Saham Konvensional di Bursa Efek Indonesia. Penelitian ini bertujuan untuk mengetahui perbedaan tingkat pengembalian dan risiko antara indeks saham JII dan LQ45. Penelitian ini mencoba untuk menjelaskan apakah terdapat perbedaan tingkat pengembalian dan risiko antara indeks saham JII dan indek saham LQ45 pada 5 (lima) tahun periode terakhir yaitu tahun 2014 sampai dengan tahun 2018. Penelitian ini juga akan menggunakan teknik pengujian yang berbeda yaitu uji mann whitney.

\section{TINJAUAN PUSTAKA}

\section{Teori Portofolio Modern}

Teori Portofolio Modern (MPT), yang diusulkan oleh Harry Markowitz (1959), telah menetapkan kerangka kerja untuk pembuatan dan investasi portofolio. Meskipun teori ini dicetuskan 
sekitar 60 tahun yang lalu, namun teori ini masih digunakan secara luas di seluruh dunia dan merupakan prosedur yang paling universal yang digunakan dalam manajemen portofolio dan perencanaan keuangan saat ini. Pada tahun 1952 Markowitz menulis disertasi dan menemukan "portfolio selection" yang memungkinan investor untuk menganalisis risiko terhadap pengembalian yang diharapkan.

MPT merupakan teori investasi yang berupaya memaksimalkan tingkat pengembalian yang diharapkan dari risiko portofolio atau meminimalkan risiko untuk tingkat pengembalian yang diharapkan, dengan memilih proporsi dari berbagai aset. Teori ini mendorong diversifikasi aset untuk melakukan perlindungan nilai terhadap risiko pasar. Teori MPT membantu investor untuk mengklasifikasikan, memperkirakan, dan mengendalikan risiko dan pengembalian yang diharapkan.

MPT secara matematis merumuskan konsep diversifikasi dalam berinvestasi, dengan tujuan memilih koleksi aset investasi yang secara kolektif memiliki risiko lebih rendah daripada aset individu mana pun. Menurut Hickman, Teets, \& Kohls (1999) semakin rendah korelasi antara saham tersebut maka portofolio tersebut disebut sebagai portofolio yang terdiversifikasi dengan baik. Portofolio yang telah terdiversifikasi dengan baik juga akan dipengaruhi oleh risiko pasar dan risiko global.

\section{Tingkat Pengembalian}

Tingkat Pengembalian adalah salah satu faktor yang memotivasi investor berinvestasi dan juga merupakan imbalan atas keberanian investor menanggung risiko atas investasi yang dilakukannya (Tandelilin, 2010). Dalam melakukan kegiatan investasi pada saham, para investor perlu melihat apakah saham tersebut memberikan tingkat pengembalian yang sesuai dengan harapan atau tidak. Dalam konteks manajemen investasi, tingkat pengembalian merupakan imbalan yang diperoleh dari investasi. Menurut Hartono (2016) Tingkat Pengembalian ini dibedakan menjadi dua, yaitu pengembalian yang telah terjadi (actual return) yang dihitung berdasarkan data historis, dan pengembalian yang diharapkan (expected return-ER) akan diperoleh investor di masa depan.

Tingkat Pengembalian yang diharapkan adalah pengembalian yang diperkirakan dan mungkin atau mungkin tidak terjadi. Tingkat Pengembalian yang terealisasi di masa lalu memungkinkan investor untuk memperkirakan arus kas masuk dalam bentuk dividen, bunga, bonus, keuntungan modal, dan lain-lain. Tersedia untuk pemegang investasi. Tingkat Pengembalian dapat diukur sebagai total keuntungan atau kerugian bagi pemegang selama periode waktu tertentu dan dapat didefinisikan sebagai persentase pengembalian dari jumlah awal yang diinvestasikan. Dengan mengacu pada investasi dalam saham ekuitas, pengembalian terdiri dari dividen dan keuntungan atau kerugian modal pada saat penjualan saham ini.

Menurut Jones, Van Der Laan, Frost, \& Loftus (2008) Tingkat Pengembalian yang diperoleh pada saham terdiri dari dua komponen, yaitu Capital gain (loss) dan Yield. Capital gain (loss) merupakan selisih harga sekarang relatif terhadap harga periode sebelumnya. Yield merupakan 
komponen tingkat pengembalian aliran kas atau pendapatan yang diperoleh secara periodik dari suatu investasi. Pada saham, yield diperlihatkan dari besarnya dividen yang diperoleh.

\section{Risiko}

Keown (1999) mendefinisikan risiko sebagai penyimpangan arus kas yang mungkin terjadi di masa yang akan datang. Risiko menurut Halim (2015) adalah besarnya penyimpangan antara tingkat pengembalian yang diharapkan dengan tingkat pengembalian secara nyata. Metode untuk menghitung risiko yang paling banyak digunakan yaitu menggunakan standar deviasi. Nilai ekspektasian yang digunakan dalam rumus standar deviasi dapat berupa nilai ekspektasian berdasarkan rata-rata historis atau trend atau random walk (Hartono, 2016).

Dalam konteks portofolio, risiko total sekuritas dapat dibagi menjadi dua komponen dasar: risiko sistematis (juga dikenal sebagai risiko pasar atau risiko bersama), dan risiko tidak sistematis (juga dikenal sebagai risiko yang dapat didiversifikasi). MPT mengasumsikan bahwa kedua jenis risiko ini umum untuk semua portofolio.

Menurut Ross et.al (2002) Risiko sistematis merupakan bentuk risiko pada tingkatan makro yang memengaruhi sejumlah besar aset hingga tingkat tertentu. Kondisi ekonomi umum, seperti inflasi, suku bunga, tingkat pengangguran, nilai tukar atau tingkat Produk Nasional Bruto adalah semua contoh faktor risiko sistematis. Jenis-jenis kondisi ekonomi ini berdampak pada hampir semua sekuritas sampai tingkat tertentu. Dengan demikian, risiko sistemis adalah tidak dapat dihilangkan. Sebaliknya, risiko tidak sistematis merupakan bentuk risiko pada tingkatan mikro. Ini melibatkan risiko khusus yang tidak terkait dengan risiko lain dan hanya berdampak pada sekuritas atau aset tertentu.

\section{Hipotesis Penelitian}

Pernyataan umum "high risk, high return" juga berlaku pada indeks saham syariah, hal ini dibuktikan oleh Touiti dan Henchiri (2017) dimana standar deviasi pada indeks saham syariah yang memiliki tingkat pengembalian yang relatif lebih tinggi dibandingkan dengan indeks saham konvensional. Selain itu, Mansor \& Bhatti (2011), Lean \& Parsva (2012) dan Kurniawan \& Nadia (2014) serta Muthoharoh \& Sutapa (2014) juga menemukan bahwa indeks saham syariah menghasilkan tingkat pengembalian (return) yang lebih tinggi dibandingkan dengan indeks saham konvensional. Berdasarkan pernyataan ini, maka hipotesis di penelitian ini adalah:

$\mathrm{H}_{1}$ : Terdapat perbedaan tingkat pengembalian indeks saham JII dan LQ45

Penelitian yang dilakukan Lean \& Parsva (2012) dan Reddy \& Mingli (2014) menyimpulkan bahwa indeks syariah memiliki kinerja yang lebih berisiko sebagaimana indeks konvensional. Penelitian tersebut juga didukung oleh Muthoharoh \& Sutapa (2014) yang menyatakan bahwa risiko saham konvensional lebih rendah daripada risiko saham syariah. Berbeda halnya dengan penelitian yang dilakukan oleh Sukmana and Kholid (2012) yang menyimpulkan bahwa indeks syariah memiliki 
risiko minimal, jika dibandingkan dengan indeks konvensional. Berdasarkan alasan ini, maka hipotesis dari penelitian ini adalah:

$\mathrm{H}_{2}$ : Terdapat perbedaan risiko indeks saham JII dan LQ45

\section{METODE PENELITIAN}

Penelitian yang dijabarkan pada bab sebelumnya tujuan utama penelitian ini adalah untuk untuk membandingkan antara dua kelompok atau lebih dari suatu variabel tertentu, maka penelitian ini dapat dikelompokkan sebagai penelitian komparatif dengan pendekatan kuantitatif. Sugiyono (2013) menyatakan penelitian komparatif adalah suatu penelitian yang bersifat membandingkan. Variabelnya masih sama dengan variabel mandiri tetapi untuk sampel yang lebih dari satu, atau dalam waktu yang berbeda. Marentek \& Febryiantoro (2018) menyatakan pendekatan kuantitatif adalah penelitian dengan memperoleh data yang berbentuk angka.

Populasi dalam penelitian ini adalah indeks saham syariah dan indeks saham konvensional yang terdaftar di Bursa Efek Indonesia (BEI). Sampel dalam penelitian ini adalah indeks saham JII (syariah) dan LQ45 (konvensional) dalam periode penelitian 2014 sampai dengan 2018. Lokasi penelitian yaitu PT Bursa Efek Indonesia atau www.idx.co.id sebagai penyedia data sekunder.

Penelitian ini menggunakan metode observasi dengan teknik observasi non partisipan yang dilakukan dengan mengumpulkan catatan tertulis mengenai berbagai kegiatan atau peristiwa pada waktu yang lalu (Pradana, 2018). Semua dokumen yang berhubungan dengan penelitian merupakan sumber informasi yang secara statistik dinamakan data sekunder. Sumber data yang digunakan adalah data harga penutupan indeks saham JII dan LQ45 selama periode penelitian dari tahun 2014 sampai dengan 2018. Indeks saham JII dan LQ45 dievaluasi setiap 6 bulan sekali. Saham-saham yang tidak memenuhi syarat akan digantikan oleh saham lain yang menyebabkan populasi indeks saham JII dan LQ45 tidak tetap.

\section{Definisi Operasional dan Pengukuran Variabel Penelitian}

Definisi operasional variabel dikembangkan dari penelitian-penelitian terdahulu melewati proses sintesa dalam penelitian ini maka dapat dijabarkan sebagai berikut:

\section{Tingkat Pengembalian}

Langkah pertama untuk mengukur tingkat pengembalian adalah dengan menghitung rata-rata pengembalian periode ke $t$ dari indeks saham JII dan LQ45. Tingkat pengembalian yang digunakan dalam penelitian ini adalah return realisasi atau sering disebut actual return. Actual return (tanpa dividen yield) dapat dihitung dengan rumus Hartono (2016) yang menggunakan data penutupan harga saham dapat dinyatakan dalam persamaan 1 .

$$
\mathrm{R}_{\mathrm{t}}=\frac{p_{t}-p_{t-1}}{p_{t-1}}
$$


Keterangan :

$\mathrm{R}_{\mathrm{t}} \quad=$ Tingkat pengembalian atau periode ke $\mathrm{t}$

$\mathrm{P}_{\mathrm{t}} \quad=$ harga saham pada periode- $\mathrm{t}$

$\mathrm{P}_{\mathrm{t}-1} \quad=$ harga saham pada periode $\mathrm{t}$ sebelumnya

\section{Risiko}

Risiko sering dihubungkan dengan penyimpangan atau deviasi dari outcome yang diterima dengan yang diekspektasi. Hartono (2016) mendefinisikan risiko sebagai variabilitas tingkat pengembalian terhadap tingakat pengembalian yang diharapkan. Untuk menghitung risiko, metode yang digunakan adalah standar deviasi yang mengukur besarnya penyimpangan nilai-nilai yang sudah terjadi dengan nilai ekspektasinya. Risiko yang diukur dengan standar deviasi yang menggunakan data historis dapat dinyatakan dalam persamaan 2.

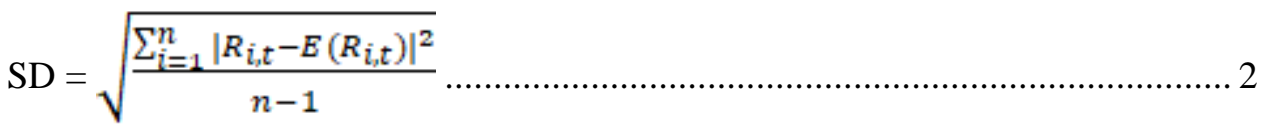

Keterangan:

$\mathrm{SD} \quad=$ standar deviasireturn saham $\mathrm{i}$

$\mathrm{R}_{\mathrm{i}, \mathrm{t}} \quad=$ rata-rata return saham i pada periode ke $\mathrm{t}$

$\mathrm{E}\left(\mathrm{R}_{\mathrm{i}, \mathrm{t})}=\right.$ tingkat pengembalian yang diharapkan saham i pada periode ke $\mathrm{t}$

$\mathrm{n} \quad=$ jumlah observasi data historis untuk sampel besar $\mathrm{n}$ (paling sedikit 30 observasi) dan untuk sampel kecil digunakan (n-1).

\section{Teknik Analisis}

Statistik deskriptif adalah statistik yang memberikan gambaran atau deskripsi suatu data yang dilihat dari mean, standard deviation, maximum, minimun, sum, range, kurtosis, dan skewness. Statistik deskriptif mendeskripsikan data menjadi sebuah informasi yang lebih jelas dan mudah dipahami (Ghozali, 2016).

Analisis statistik deskriptif dimaksudkan untuk mengetahui distribusi tingkat pengembalian dan risiko yang terdapat pada indeks saham JII dan LQ45. Dengan cara mengumpulkan data harga penutupan saham dari Bursa Efek Indonesia selanjutnya ditabulasi dalam tabel dan dilakukan pembahasan secara deskriptif.

Analisis statistik inferensial memfokuskan pada bidang kajian analisis dan interpretasi data untuk menarik kesimpulan. Analisis ini digunakan untuk menguji hipotesis penelitian yang telah ditetapkan dengan menggunakan data sampel yang diperoleh. Metode Statistik Inferensial yang digunakan dalam analisis data penelitian ini adalah Uji Normalitas, Uji Homegenitas, dan Uji Mann Whitney. 


\section{HASIL DAN PEMBAHASAN}

\section{Karakteristik Variabel}

Data yang digunakan dalam penelitian ini adalah data sekunder dengan indeks saham JII dan LQ45 di Bursa Efek Indonesia (BEI) sebagai objek penelitiannya. Data yang dikumpulkan adalah harga penutupan saham dengan horizon waktu tahun 2014 sampai dengan 2018. Informasi mengenai penelitian disajikan pada Tabel 1 berikut ini:

Tabel 1. Daftar Penelitian

\begin{tabular}{lc}
\hline Keterangan & Jumlah \\
\hline Indeks saham JII & 30 Perusahaan \\
Indeks saham LQ45 & 45 perusahaan \\
Periode penelitian & 5 tahun \\
Data Tingkat Pengembalianindeks saham JII & 60 \\
Data Tingkat Pengembalian indeks saham LQ45 & 60 \\
Data Risiko indeks saham JII & 60 \\
Data Risiko indeks saham LQ45 & 60 \\
\hline
\end{tabular}
Sumber: Data sekunder diolah (2019).

Indeks Saham JII dan LQ45 yang terdaftar di Bursa Efek Indonesia adalah 30 dan 45 perusahaan. Dengan observasi data berturut-turut selama 5 tahun, jumlah data yang digunakan untuk penelitian adalah sebanyak 240 data dimana terdapat data tingkat pengembalian indeks saham JII dan LQ45 sebanyak 60 data dan data risiko indeks saham JII dan LQ45 sebanyak 60 data. Data tersebut kemudian diproses dengan menggunakan program Statistical Package for the Social Sciences (SPSS) versi 22 dengan hasil dari masing-masing statistik deskriptif disajikan dalam tabel 2 di bawah ini.

Tabel 2. Hasil Uji Statistik Deskriptif

\begin{tabular}{lccccc}
\hline & N & Minimum & Maximum & Mean & $\begin{array}{c}\text { Std. } \\
\text { Deviation }\end{array}$ \\
\hline Return JII & 60 & -0.875 & 0.701 & 0.003767 & 0.359263 \\
Risk JII & 60 & 0.0047 & 0.0248 & 0.011180 & 0.003896 \\
Return LQ45 & 60 & -0.962 & 0.888 & 0.006370 & 0.384404 \\
Risk LQ45 & 60 & 0.0048 & 0.0254 & 0.011010 & 0.004185 \\
\hline
\end{tabular}

Sumber: Data sekunder diolah (2019).

Hasil uji statistik deskriptif pada tabel diatas menunjukkan tingkat pengembalian indeks saham JII memiliki nilai terkecil (minimum) sebesar -0.875 dan nilai terbesar (maximum) sebesar 0.701. Ratarata tingkat pengembalian indeks saham JII menunjukkan hasil yang positif sebesar 0.003767 artinya secara umum tingkat pengembalian saham yang diterima positif (mengalami keuntungan). Nilai standar deviasi tingkat pengembalian saham sebersar 0.359263 (diatas rata-rata), artinya tingkat pengembalian saham memiliki tingkat variasi data yang tinggi. Hasil uji statistik deskriptif pada tingkat pengembalian indeks saham LQ45 memiliki nilai terkecil (minimum) sebesar -0.962 dan nilai terbesar (maximum) sebesar 0.888. Rata-rata tingkat pengembalian indeks saham LQ45 menunjukkan hasil yang positif sebesar 0.006370 artinya secara umum tingkat pengembalian saham yang diterima 
positif (mengalami keuntungan). Nilai standar deviasi tingkat pengembalian saham sebesar 0.384404 (diatas rata-rata), artinya tingkat pengembalian saham memiliki tingkat variasi data yang tinggi.

Hasil uji statistik deskriptif pada risiko indeks saham JII memiliki nilai terkecil (minimum) sebesar 0.0047 dan nilai terbesar (maximum) sebesar 0.0248. Rata-rata risiko indeks saham JII sebesar 0.011180 dan standar deviasi sebesar 0.003896. Hasil uji statistik deskriptif pada risiko indeks saham LQ45 memiliki nilai terkecil (minimum) sebesar 0.0048 dan nilai terbesar (maximum) sebesar 0.0254. Rata-rata risiko indeks saham JII sebesar 0.011010 dan standar deviasi sebesar 0.004185 .

\section{Uji Normalitas}

Berdasarkan hasil pengujian normalitas pada Tabel 3, nilai signifikansi untuk tingkat pengembalian dan risiko indeks saham JII dan LQ45 menunjukkan angka kurang dari 0.05 , artinya data tidak distribusi normal. Menurut Hidayat (2014), salah satu asumsi Uji Mann Whitney digunakan adalah data variabel tidak memenuhi asumsi normalitas. Hal itu mengindikasikaan bahwa uji mann whitney layak untuk digunakan dalam penelitian ini.

Tabel 3. Hasil Uji Normalitas

\begin{tabular}{lcc}
\hline & Shapiro-Wilk & Kesimpulan \\
\hline Return JII & 0.018 & Distribusi Tidak Normal \\
Risk JII & 0.011 & Distribusi Tidak Normal \\
Return LQ45 & 0.004 & Distribusi Tidak Normal \\
Risk LQ45 & 0.001 & Distribusi Tidak Normal \\
\hline
\end{tabular}

Sumber: Data sekunder diolah (2019).

\section{Uji Homogenitas}

Berdasarkan hasil pengujian homogenitas diperoleh nilai signifikansi tingkat pengembalian indeks saham JII dan LQ45 sebesar $0.829>0.05$, yang berarti data homogen atau mempunyai varian yang sama. Nilai risko indeks saham JII dan LQ45 sebesar $0.460>0.05$, yang berarti data homogen atau mempunyai varian yang sama. Hasil pengujian homogenitas dapat dilihat pada Tabel 4

Tabel 4. Hasil Uji Homogenitas

\begin{tabular}{ccccc}
\hline Kelompok & Kategori & Levene Statistic & Sig. & Kesimpulan \\
\hline $\begin{array}{c}\text { Indeks Saham JII dan } \\
\text { LQ45 }\end{array}$ & $\begin{array}{c}\text { Pengembalian } \\
\text { Risiko }\end{array}$ & 0.047 & 0.829 & Homogen \\
& 0.549 & 0.460 & Homogen \\
\hline
\end{tabular}

Sumber: Data sekunder diolah (2019).

\section{Uji Mann Whitney}

Hasil uji Mann Whitney digunakan untuk menguji perbedaan tingkat pengembalian dan risiko indeks saham JII terhadap indeks saham LQ45. Pengujian Hipotesis pada penelitian ini dilakukan 
dengan berdasar pada nilai signifikansi yang diperoleh pada pengujian Mann Whitney. Apabila nilai signifikansi kurang dari 0,05 maka hipotesis menunjukkan ada perbedaan yang signifikan. Sebaliknya, jika nilai signifikansi lebih dari 0,05 maka hipotesis menunjukkan tidak memiliki perbedaan yang signifikan. Hasil uji Mann Whitney dapat dilihat pada Tabel 5 dan Tabel 6

Tabel 5. Hasil Uji Mann Whitney Tingkat Pengembalian Indeks Saham JII dan LQ45

\begin{tabular}{ccc}
\hline Tahun & $\begin{array}{c}\text { Asymp. Sig. } \\
\text { (2-tailed) }\end{array}$ & Kesimpulan \\
\hline 2014 & 0.686 & Tidak ada perbedaan signifikan \\
2015 & 0.954 & Tidak ada perbedaan signifikan \\
2016 & 0.862 & Tidak ada perbedaan signifikan \\
2017 & 0.386 & Tidak ada perbedaan signifikan \\
2018 & 0.862 & Tidak ada perbedaan signifikan \\
Total & 0.492 & Tidak ada perbedaan signifikan \\
\hline
\end{tabular}

Sumber: Data sekunder diolah (2019).

\section{Hasil Pengujian Hipotesis 1 (H1)}

Hasil penelitian menunjukkan nilai signifikansi tingkat pengembalian indeks saham JII dan LQ45 secara keseluruhan dari tahun 2014 sampai dengan 2018 sebesar 0.492. Hal ini menunjukkan bahwa tidak ada perbedaan signifikan dalam tingkat pengembalian.

Tabel 6. Hasil Uji Mann Whitney Tingkat Risiko Saham JII dan LQ45

\begin{tabular}{ccc}
\hline Tahun & $\begin{array}{c}\text { Asymp. Sig. } \\
\text { (2-tailed) }\end{array}$ & Kesimpulan \\
\hline 2014 & 0.977 & Tidak ada perbedaan signifikan \\
2015 & 0.817 & Tidak ada perbedaan signifikan \\
2016 & 0.260 & Tidak ada perbedaan signifikan \\
2017 & 0.686 & Tidak ada perbedaan signifikan \\
2018 & 1.000 & Tidak ada perbedaan signifikan \\
Total & 0.508 & Tidak ada perbedaan signifikan \\
\hline
\end{tabular}

Sumber: Data sekunder diolah (2019).

\section{Hasil Pengujian Hipotesis 2 (H2)}

Hasil penelitian menunjukkan nilai signifikansi risiko indeks saham JII dan LQ45 secara keseluruhan dari tahun 2014 sampai dengan 2018 sebesar 0.508. Hal ini menunjukkan bahwa tidak ada perbedaan signifikan dalam risiko.

Berdasarkan hasil uji di atas, ditemukan bahwa tidak adanya perbedaan yang signifikan antara tingkat pengembalian dan risiko antara indeks saham JII dan LQ45. Sebagian besar saham yang termasuk dalam indeks saham JII juga termasuk dalam indeks LQ45. Hal ini dapat dibuktikan dengan data saham indeks JII periode 2014 sampai dengan 2018, dimana dari 30 saham yang terdapat di indeks saham JII, 13 saham atau sebesar 43,3\% diantaranya merupakan saham yang teradapat dalam 
indeks saham LQ45. Hal ini menunjukkan bahwa sebagian besar indeks saham syariah merupakan likuiditas tinggi dan kapitalisasi pasar besar.

Hasil ini sesuai dengan penelitian yang dilakukan oleh Ata \& Buğan (2015) yaitu tidak ada perbedaan tingkat pengembalian terhadap indeks Dow Jones dan morgan stanley. Hasil penelitian yang dilakukan oleh Barau (2016) yaitu tidak ada perbedaan risiko terhadap indeks saham syariah dan konvensional di GCC. Hasil penelitian yang dilakukan oleh Setiawan \& Oktariza (2013) menunjukkan bahwa tidak ada perbedaan signifikan antara tingkat pengembalian dan risiko antara saham syariah dan konvensional. Hal ini menunjukkan bahwa kriteria penyaringan yang diterapkan untuk saham syariah tidak mempengaruhi kinerja saham dibandingkan dengan saham konvensional.

\section{KESIMPULAN}

Berdasarkan uraian-uraian yang telah dijelasakan pada pembahasan sebelumnya, maka dapat diambil beberapa kesimpulan yaitu:

1. Tidak terdapat perbedaan signifikan tingkat pengembalian antara indeks saham JII dan LQ45 secara statistik .

2. Tidak terdapat perbedaan signifikan risiko antara indeks saham JII dan LQ45.

\section{SARAN}

Beberapa saran yang dapat disampaikan oleh peneliti terkait dengan penelitian ini adalah sebagai berikut:

1. Untuk penelitian selanjutnya, sebaiknya menambah tahun penelitian.

2. Penelitian berikutnya dapat menggunakan variabel lain seperti rasio profitabilitas dan rasio likuiditas.

3. Memperbanyak literatur-literatur pendukung yang dapat menjelaskan variabel.

4. Bagi investor muslim sebaiknya berinvestasi pada saham yang terdapat pada Jakarta Islamic Index, mengingat tingkat pengembalian dan risiko yang didapat tidak jauh berbeda dengan yang konvensional.

\section{REFERENSI}

Abbes, M. B. 2012. Risk and Return of Islamic and Conventional Indices. International Journal of Euro-Mediterranean Studies. Diambil dari https://doi.org/10.1007/s40321-012-0001-9

Arthur J. Keown, David F. Scott, Jr., John D. Martin, J. William Petty. 1999. Dasar-dasar Manajemen Keuangan. Jakarta: Salemba Empat.

Ata, H. A., \& Buğan, M. F. 2015. Comparison of the Performances Islamic and Conventional Market Indices and their Causal Relationship. International Journal of Business Management and Economic Research.

Badan Pusat Statistik, 2010. Data Statistik Indonesia. Penduduk Menurut Kelompok Umur dan Agama yang Dianut. Jakarta Pusat: Badan Pusat Statistik. Diambil dari: https://sp2010.bps.go.id/index.php 
Barau, A.M. 2016. Did Islamic Equities Outperform Conventional Equities in the Gulf Cooperation Council (GCC) Region during and after the Global Financial Crisis. Research Journal of Finance and Accounting. ISSN 2222-1697, Vol. 7, No. 8, 2016.

Ghozali, Imam. 2016. Aplikasi Analisis Multivariete Dengan Program IBM SPSS 23 (Edisi 8). Cetakan ke VIII. Semarang : Badan Penerbit Universitas Diponegoro.

Halim, Abdul. 2015. Analisis Investasi dan Aplikasinya. Jakarta: Salemba Empat.

Hartono, J. 2016. Teori Portofolio dan Analisis Investasi. Yogyakarta: BPFE.

Hickman, K. A., Teets, R., \& Kohls, J. J. 1999. Social investing and modern portfolio theory. American Business Review. Vol. 17(3), 72-78.

Hidayat, Anwar. 2014. Penjelasan Uji Mann Whitney U Test. Diambil dari: https://www.statistikian.com/2014/04/mann-whitney-u-test.html. (04 November 2019)

Hussein, K., \& Omran, M. 2005. Ethical Investment Revisited: Evidence from Dow Jones Islamic Indexes. Journal of Investing (ISSN: 10680896). Diambil dari: https://doi.org/10.3905/joi.2005.580557

Jones, S., Van Der Laan, S., Frost, G., \& Loftus, J. 2008. The investment performance of socially responsible investment funds in Australia. Journal of Business Ethics. Diambil dari: https://doi.org/10.1007/s10551-007-9412-6

Kurniawan, Rizki Dwi \& Nadia Asandimitra. 2014. Analisis Perbandingan Kinerja Indeks Saham Syariah dan Kinerja Indeks Saham Konvensional. Jurnal Ilmu Manajemen, Vol. 2 (4), 13541366.

Lean, H. H., \& Parsva, P. 2012. Performance of Islamic Indices in Malaysia FTSE market: Empirical evidence from CAPM. Journal of Applied Sciences, Vol. 12(12), 1274-1281. Diambil dari: https://doi.org/10.3923/ 1as.2012.1274.128

Mansor, F. dan M. Ishaq Bhatti. 2011. The Islamic Mutual Fund Performance: New Evidence on Market Timing and Stock Selectivity. International Conference on Economics and Finance Research.

Marentek, T. K. W. Y., \& Febryiantoro, M. T. 2018. Penentuan Fungsi Linear yang Ideal Pada Model Ekonomi Fungsi Penawaran. Eksis: Jurnal Riset Ekonomi Dan Bisnis. Diambil dari: https://doi.org/10.26533/eksis.v13i1.153

Markowitz, H. 1959. Portfolio Selection. New Haven, Connecticut: Yale University Press.

McGowan, Jr., C. B., \& Muhammad, J. 2016. The Theoretical Impact Of The Listing Of SyariahApproved Stocks On Stock Price And Trading Volume. International Business \& Economics Research Journal (IBER). Diambil dari: https://doi.org/10.19030/iber.v9i3.532

Muthoharoh \& Sutapa. 2014. Perbandingan Saham Berbasis Syariah Dengan Saham Konvensional Sebagai Analisa Kelayakan Investasi Bagi Investor Muslim. Jurnal Akuntansi Indonesia. Vol. 3 (2), 101-112

Otoritas Jasa Keuangan. 2016. Survei Nasional Literasi dan Inklusi Keuangan 2016 (National Literacy and Financial Inclusion Survey 2016). Survey Report.

Pradana, M. N. R. 2018. Pengaruh Likuiditas dan Variabel Eksternal Terhadap Non Performing Financing Pada Bank Syariah. Jurnal Riset Ekonomi dan Bisnis. Vol. 13(2), 131-144.

PT Bursa Efek Indonesia. 2018. Saham. Diambil dari: http://www.idx.co.id/produk/saham/

Qalbi, Nur. 2019. Per Maret 2019, baru 19\% dari 50.048 investor syariah yang aktif. diambil dari: https://investasi.kontan.co.id/news/per-maret-2019-baru-19-dari-50048-investor-syariah-yangaktif. (22 Mei 2019)

Reddy, Krishna \& Mingli Fu. 2014. Does Shariah Compliant Stocks Perform Better Than Conventional Stocks? A Comparative Study of Stocks Listed on The Australian Stock Exchange. Asian Journal of Finance \& Accounting. Vol. 6 (2), 155-170.

Ross, S. Westerfield, R. \& Jaffe, J. 2002. Capital market theory: An overview. Corporate finance (6th ed.) (226-247). New York, NY: McGraw-Hill.

Setiawan, C., \& Oktariza, H. 2013. Syariah and conventional stocks performance of public companies listed on Indonesia Stock Exchange. Journal of Accounting, Finance and Economics.

Sinarti dan Ainun Na'im. 2010. Kinerja Akuntansi dan Kinerja Pasar Modal pada Perusahaanperusahaan dalam Jakarta Islamic Index. Simposium Nasional Akuntansi Purwokerto, 2010. http://www.sna13purwokerto.com 
Sugiyono. 2013. Metode Penelitian Pendidikan Pendekatan Kuantitatif, Kualitatif, dan R\&D. Bandung: Alfabeta.

Sukmana, Raditya, and Muhamad Kholid. 2012. "Impact of Global Financial Crisis on Islamic and Conventional Stocks in Emerging Market: An Application of ARCH and GARCH Method." Asian Academy of Management Journal of Accounting \& Finance.

Tandelilin, Eduardus. 2010. Portofolio dan Investasi Teori dan Aplikasi. Edisi pertama. Yogyakarta: Kanisius

Touiti, M. \& Henchiri, J.E. 2017. Risk and Performance of Islamic Indexes during Subprime Crisis. Proceedings of the Second American Academic Research Conference on Global Business, Economics, Finance and Social Sciences (AARI17 New York Conference) ISBN: 9789435796.

Walkshäusl, C., \& Lobe, S. 2012. Islamic investing. Review of Financial Economics. Diambil dari: https://doi.org/10.1016/j.rfe.2012.03.002 